\title{
PEMANFAATAN TEPUNG UMBI GADUNG (DIOSCOREA HISPIDA DENNST) MENJADI KUE KERING KAASTENGELS
}

\author{
Putu Adi Periawan, Cokorda Istri Raka Marsiti, Made Suriani. \\ Jurusan Pendidikan Kesejahteraan Keluarga \\ Universitas Pendidikan Ganesha \\ Singaraja, Indonesia \\ e-mail : putuadiperiawan1996@gmail.com,Cokistrimarsiti@yahoo.com, \\ made.suriani@undiksha.ac.id,
}

\begin{abstract}
Abstrak
Penelitian eksperimen ini bertujuan untuk mendeskripsikan (1) kualitas kue kering kaastengels tepung gadung yang dilihat dari aspek rasa, warna dan tekstur. Metode pengumpulan data yang digunakan dalam penelitian ini yaitu metode observasi dengan menggunakan instrumen berupa uji lembar organoleptik dengan 3 tingkat yaitu baik, cukup dan kurang. Panelis dalam penelitian ini merupakan panelis terlatih yang terdiri dari 25 orang panelis. Teknik analisis data digunakan teknik deskriptif kuantitatif. Hasil penelitian menunjukkan kualitas kue kering kaastengels tepung gadung dilihat dari aspek (1) rasa dengan skor rata-rata 2,84 berada pada kategori baik sesuai dengan tolak ukur rasa gurih dan terasa keju, (2) aspek warna dengan skor rata-rata 2,84 berada pada kategori baik sesuai dengan tolak ukur warna kuning keemasan, (3) aspek tekstur dengan skor rata-rata 2,72 berada pada kategori baik dengan tolak ukur memiliki tekstur rapuh dan tidak mudah patah.
\end{abstract}

Kata Kunci : Kue Kering Kaastengels, Kualitas, Tepung Gadung.

\begin{abstract}
This eksperimental study is aims at describing the (1) quality of kaastengels cookies of a gadung flour that is seen in the sense of the taste, colour and textures. The method of collecting data used in this study is an observation method using the instrument of a form of organicptic tissue test with 3 levels is good, enough and less. Panelists in this study were trained panelists consisting of 25 panelists. Data analysis techniques used quantitative descriptive techniques. The results showed that the quality of gadung flour kaastengels cookies was seen from aspects (1) of taste with an average score of 2,84 in the good category, (2) colour aspects with an average score 2,84 in the good category according to the golden yellow benchmark, (3) textural aspects with an average score of 2,72 are in the good category with benchmark having a brittle texture and not easily broken.
\end{abstract}

Keywords: Kaastengels cookies, quality, gadung flour.

\section{PENDAHULUAN}

Ketahanan pangan adalah tersedianya pangan yang cukup, merata dan terjangkau dan setiap orang mampu mengkonsumsi pangan yang aman dan bergizi sesuai pilihannya guna menjalani kehidupan sehat dan produktif. Salah satu kebijakan ketahanan pangan adalah penganekaragaman konsumsi pangan.
Hal tersebut didasarkan pada kenyataan bahwa ketahanan pangan yang hanya bergantung pada satu jenis pangan rentan terhadap perubahan lingkungan global. Saat ini mulai sering terjadi kekeringan dan musibah banjir sebagai dampak perubahan iklim global, dan berpengaruh terhadap ketersediaan pangan yang 
terbatas dengan harga yang semakin mahal dan tidak terjangkau penduduk berpenghasilan rendah. Pada kondisi demikian, perlu alternatif pangan murah, terjangkau dan tersedia. Indonesia merupakan salah satu negara yang kaya akan sumber daya alam dengan segala flora dan fauna. Berbagai macam jenis tanaman dan tumbuhan yang dapat dihasilkan di sektor pertanian dan kehutanan. Salah satu jenis tanaman yang dapat tumbuh dan berkembang di Indonesia adalah Umbi Gadung. Tanaman gadung (Dioscorea Hispida Dennst) merupakan salah satu jenis umbi-umbian yang terdapat di beberapa wilayah Indonesia.

Menurut (Rukmana 2001:10), silsilah tanaman gadung berasal dari India bagian barat. Tanaman gadung ditemukan tumbuh liar di hutan tanah kering di Himalaya, kemudian dibudidayakan di pekarangan rumah atau tegalan. Dalam perkembangan selanjutnya, tanaman gadung tersebar ke daerah tropik di Asia Tenggara, termasuk Indonesia. Di wilayah Nusantara, tanaman gadung umumnya tumbuh liar di hutan atau tegalan. Tanaman ini mampu tumbuh dengan baik di daerah dataran rendah sampai ketinggian $850 \mathrm{~m}$ di atas permukaan laut, dan bahkan juga ditemukan tumbuh di daerah yang memiliki ketinggian hingga $1.200 \mathrm{~m}$. Gadung merupakan tanaman merambat yang tumbuh liar. Umbi gadung memiliki bentuk bulat diliputi rambut akar. Selain itu, umbi gadung juga memiliki batang bulat, berbulu dan berduri yang tersebar di sepanjang batang dan tangkai daun. Kulit umbi gadung berwarna coklat muda, sedangkan daging umbinya berwarna putih. Sebagai sumber karbohidrat, gadung jarang dikonsumsi sebagai makanan utama karena jika proses pengolahannya yang tidak sempurna maka dapat menyebabkan keracunan bagi yang mengkonsumsinya. Gadung merupakan salah satu sumber pangan berkarbohidrat tinggi yang didominasi oleh pati. Umbi gadung dapat dijadikan sebagai bahan pokok pengganti beras karena memiliki kandungan gizi yang cukup lengkap.
Selain memiliki kandungan karbohidrat yang cukup tinggi gadung juga mengandung senyawa racun berbahaya, yaitu asam sianida ( $\mathrm{HCN}$ ) yang dapat menyebabkan keracunan bahkan dapat mematikan. Asam sianida yang terkandung dalam gadung berwarna biru, karena dalam jumlah tinggi tampak berwarna kebiru-biruan atau dikenal sebagai asam prusik yang timbul saat jaringan umbi gadung dirusak, misalnya dikupas atau diiris.( Kabelan Kurnia, 2002)

Penghilangan racun-racun pada umbi gadung yang biasa dilakukan oleh masyarakat umum adalah dengan menggunakan cara tradisional, yaitu dengan cara perendaman irisan umbi gadung dalam air yang mengalir. Tetapi cara tradisional tersebut masih terdapat banyak kekurangan, antara lain dapat menimbulkan kualitas produk yang tidak seragam, umbi yang mengalami pembusukan, limbah air setelah perendaman yang dapat berbahaya bagi lingkungan, serta masih tersisanya kandungan racun $\mathrm{HCN}$ dalam produk gadung yang dihasilkan. Secara umum untuk menghilangkan racun yang ada dalam umbi gadung adalah penggunaan abu. Penggunaan abu ini difungsikan untuk mempercepat penghilangan $\mathrm{HCN}$ yang terkandung dalam umbi gadung. Tahap penanganannya adalah sebagai berikut :

a. Umbi dibersihkan dari tanah yang melekat dan langsung dikupas kulitnya, pengupasan kulit harus cukup tebal.

b. Umbi gadung selanjutnya diremas-remas sampai cairan yang mengandung racun itu keluar.

c. Umbi gadung diperam selama 2x24 jam dan diatasnya diberi pemberat agar umbi tetap tertekan didalam air.

d. Setelah diperam didalam air umbi dilumuri abu atau kapur, kemudian dijemur sampai kering. 
e. Umbi yang telah kering kemudian dibersihkan dengan cara merendamnya kembali kedalam air mengalir selama $2 \times 24$ jam.

f. Setelah bersih, umbi dijemur kembali sampai kering untuk selanjutnya ketahap proses penepungan.

Penanganan tanaman umbi gadung dengan metode tersebut dapat menurunkan $\mathrm{HCN}$ yang terkandung dalam umbi gadung sebesar $10 \mathrm{mg}$ dalam setiap kilogram umbi gadung yang diolah. (Novalinda, 2015)

Tepung gadung dapat dimanfaatkan seperti halnya tepung lain, yaitu untuk bahan baku/campuran produk kue, roti dan mie. Penggunaan tepung umbi gadung dapat dicampur dengan tepung terigu atau tepung kacangkacangan untuk meningkatkan nilai gizinya. Proses pembuatan tepung gadung meliputi pengupasan, pengirisan, pengeringan dan tahap terakhir yaitu penggilingan atau penepungan( Ratri, 2014: 34)

Pada dasarnya dalam pembuatan produk kue, roti dan mie menggunakan adonan yang berbahan dasar tepung terigu sebagai kerangka. Namun dengan meningkatnya tingkat impor tepung terigu dari berbagai negara lain menyebabkan harga bahan pangan tepung terigu mengalami kenaikan. Peningkatan yang terjadi terhadap tingkat impor tepung terigu disebabkan karena tepung terigu merupakan bahan utama pangan pokok sehari-hari di Indonesia. Penyebab lainnya adalah dikarenakan harga beras yang terus mengalami peningkatan harga. Dari permasalahan di atas, penulis mempertimbangkan untuk memanfaatkan tepung umbi gadung sebagai bahan alternatif untuk membuat kue kering.

Dalam penelitian sebelumnya oleh Eha Juleha, dkk (2016) dengan judul penelitian "Pemanfaatan Tepung Gadung (DIOSCOREA HISPIDA DENNS) pada Produksi Amilase Menggunakan Bacillus $S P$ " dengan hasil penelitian menujukkan penggunaan tepung gadung yang tidak dilakukan perendaman atau perlakuan dan banyak mengandung senyawa dioskorin menghasilkan kadar gula reduksi yang tinggi sehingga total aktivitas dan rendemen enzim emilase yang didapatkan juga tinggi dibandingkan dengan sampel yang lainnya yaitu dari tepung dan pati gadung yang lebih sedikit mengandung dioscorin.

Dalam penelitin kedua oleh Visensia Iva Rosmeri dan Bella Nina Monica (2013) dengan judul penelitian "Pemanfaatan Tepung Umbi Gadung (Dioscorea Hispida Dennst) dan Tepung MOCAF (Modified Cassava Flour) Sebagai Substitusi dalam Pembuatan Mie Basah, Mie Kering, dan Mie Instan" dengan hasil penelitian menunjukkan mie basah kualitas terbaik diperoleh daro kombinasi $40 \%$ tepung gadung dan $60 \%$ tepung gandum sedangkan mie basah dari tepung mocaf-tepung gandum terbaik dari kombinasi $20 \%$ tepung mocaf dan $80 \%$ tepung gandum. Mie instan terbaik diperoleh dari kombinasi $40 \%$ tepung gadung dan $60 \%$ tepung gandum, sedangkan mie instan dari tepung mocaftepung gandum terbaik dari kombinasi $20 \%$ tepung mocaf dan $80 \%$ tepung gandum. Untuk mie kering, hasil terbaiknya diperoleh dengan perbandingan $20 \%$ tepung gadung dan $80 \%$ tepung gandum, sedangkan mie kering dari tepung mocaf - tepung gandum terbaik diperoleh dari kombinasi $20 \%$ tepung mocaf dan $80 \%$ tepung gandum.

Berdasarkan penelitian di atas terkait dengan pemanfaatan tepung gadung, penulis tertarik melanjutkan penelitian dari uji kualitas tepung gadung menjadi olahan suatu produk kue kering kaastengels, yang dalam pembuatannya akan menggunakan tepung gadung sebagai bahan utama pembuatan kue kering kaastengels. Pembuatan kue kering kaastengels dari tepung gadung merupakan salah satu inovasi baru dalam pemanfaatan tepung gadung agar memiliki nilai lebih di mata masyarakat dan dapat membantu meningkatkan penggunaan pangan lokal dan mengurangi ketergantungan terhadap tepung terigu. 
Jurnal Bosaparis: Pendidikan Kesejahteraan Keluarga

Volume 10, Nomor 2, Juli 2019

Tabel 1.1

Kandungan Tepung Gadung Per 100 Gram

\begin{tabular}{|c|c|}
\hline Komponen & Nilai \\
\hline Lemak & $4,68 \%$ \\
\hline Protein & $6,37 \%$ \\
\hline Serat kasar & $39,39 \%$ \\
\hline Air & $0,85 \%$ \\
\hline Abu & $2,74 \%$ \\
\hline $\mathrm{HCN}$ & $430,96 \mathrm{ppm}$ \\
\hline
\end{tabular}

(Sumber : Catur, dkk. 2017)

Berdasarkan tabel di atas tepung gadung memiliki kandungan lemak sebesar 4,68\%, protein sebesar 6,37\%, serat kasar 39,39\%, air sebesar 0,85\%, dan abu sebesar 2,74\%. Dari hasil tersebut menunjukkan bahwa tepung gadung sangat baik digunakan untuk pembuatan kue kering karena dilihat dari karakteristiknya, tepung gadung memiliki kandungan protein yang rendah dimana dalam pembuatan kue kering mempergunakan tepung yang kadar proteinnya rendah. Seperti yang diketahui bahwa konsumsi kue kering di masyarakat tergolong tinggi. Kue kering biasa disajikan pada kegiatan imlek, lebaran, acara pernikahan, natal dan acara keluarga lainnya sebagai cemilan. Sehingga hal ini dapat memacu masyarakat berinovasi dalam pemanfaatan pangan lokal sebagai olahan yang memberikan nilai lebih dan dapat membuka peluang baru bagi usaha industri maupun rumah tangga.

Kaastengels merupakan kue kering yang cukup populer di Indonesia yang prosesnya di panggang di oven. Kaastengels merupakan jenis kue kering yang banyak di jual di toko-toko roti. Secara garis besar bahan dasar pembuatan kue kaastengels menggunakan tepung yang berkadar protein rendah. Hal ini sejalan dengan kadar protein tepung gadung yaitu $6,37 \%$ yang tergolong ke dalam kandungan protein rendah. Oleh karena itu peneliti memanfaatkan tepung gadung sebagai bahan eksperimen dalam pembuatan kue kaastengels. Kualitas yang diharapkan yaitu dari segi rasa, warna dan tekstur. Dari segi rasa peneliti mengharapkan rasa kue kaastengels gurih, khas keju, dari segi warna diharapkan berwarna kuning keemasan, dan dari segi tekstur diharapkan kue kaastengels bertekstur rapuh dan renyah.

\section{METODE}

Jenis penelitian ini adalah penelitian eksperimen yang meneliti tentang kue kering kaastengels dari bahan tepung umbi gadung (Dioscorea Hispida Dennst) yang dinilai dari aspek rasa, warna dan tekstur. Berikut ini adalah rancangan penelitian kue kering kaastengels yang dapat dilihat dalam bagan dibawah : 
Rancangan Penelitian

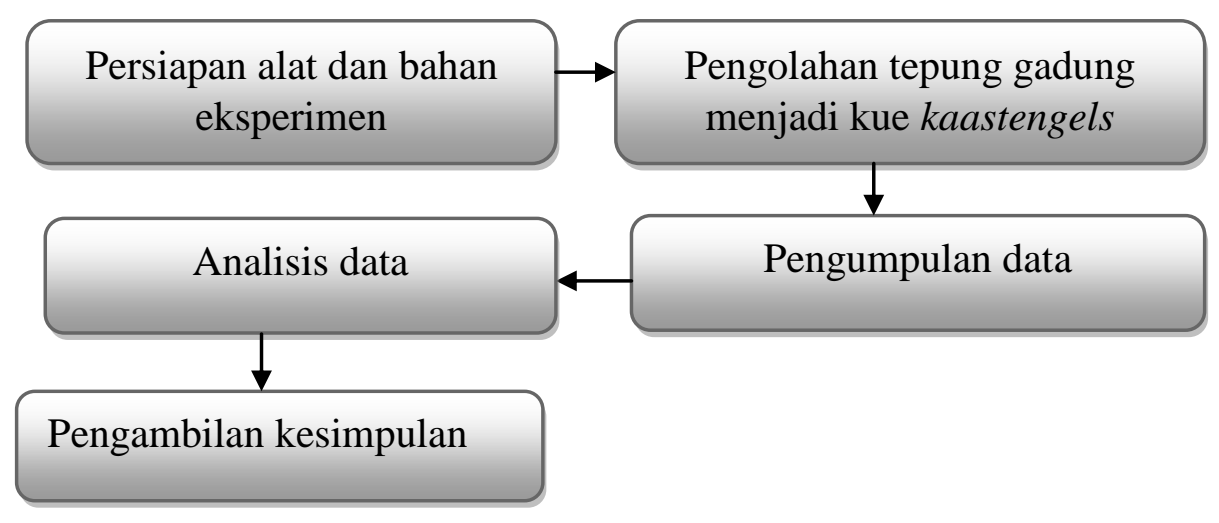

Dalam penelitian ini tepung gadung sebelum diolah menjadi produk kue kering kaastengels melalui beberapa tahapan. Pertama tahap persiapan, tahap pengolahan, dan tahap pengujian. Pada tahap persiapan, cacah gadung digiling halus menjadi tepung. Sehingga mempermudah pengolahan dari tepung menjadi produk kue kering kaastengels.

Tahap kedua yaitu tahap pengolahan yang dilakukan setelah umbi gadung menjadi tepung yang siap diolah menjadi kue kering. Adapun kue kering yang dibuat adalah kue kering kaastengels. Kue kering kaastengels dibuat dengan menggunakan bahan tepung gadung. Kualitas tekstur yang diharapkan yaitu keadaan fisik kue kering kaastengels dapat dilihat dari tingkat kerapuhan kue kering tersebut, sedangkan kualitas warna yang diharapkan yaitu warna kue kaastengels kuning keemasan dan kualitas rasa yang diharapkan yaitu rasa kue kaastengels gurih, khas keju.

Tahap ketiga yaitu tahap pengujian, yang dimana melakukan uji kualitas terhadap kue kering kaastengels dari tepung gadung yang dilihat dari aspek rasa, warna dan teksturnya dengan 25 panelis menggunakan lembar observasi. Dari hasil uji tersebut akan diperoleh data yang kemudian dianalisis sehingga mendapat kesimpulan.
Penelitian ini dilakukan di laboratorium Tata Boga Jurusan Pendidikan Kesejahteraan Keluarga Universitas Pendidikan Ganesha (Undiksha) Singaraja dan waktu yang dibutuhkan pada bulan Oktober 2018.

Variabel merupakan objek penelitian atau segala penelitian dari suatu objek yang menjadi titik fokus perhatian suatu penelitian tersebut (Agung, 1999:40). Dalam penelitian ini yang menjadi variabel atau titik fokus suatu penelitian adalah kualitas kue kering kaastengels dilihat dari segi rasa, warna dan tekstur.

Kaastengels adalah kue kering yang terbuat dengan bahan dasar tepung, margarin, keju, dan telur yang memiliki rasa gurih khas keju, warna kuning keemasan dan memiliki tekstur rapuh yang tidak mudah patah. Kualitas kue kering kaastengels adalah tingkat baik buruknya kue kaastengels dilihat dari segi rasa, warna dan tekstur. Penentuan kualitas produk makanan umumnya tergantung pada beberapa faktor diantaranya rasa, warna dan tekstur. Rasa adalah tanggapan indera terhadap rangsangan saraf seperti manis, pahit, masam terhadap indera pengecap. Rasa kue kering kaastengels yang diharapkan dalam penelitian ini adalah rasa gurih khas keju. Warna adalah kesan yang diperoleh mata dari cahaya atau warna yang ditimbulkan oleh benda yang 
dikenainya. Warna kue kering kaastengels yang diharapkan dalam penelitian ini adalah kuning keemasan. Tekstur adalah keras lembutnya, halus dan kasarnya suatu produk makanan. Tekstur kue kering kaastengels yang diharapkan dalam penelitian ini adalah rapuh dan tidak mudah patah.

Penelitian yang dilakukan terhadap kue kering kaastengels dari tepung gadung menggunakan uji organoleptik yang meliputi penilaian rasa, warna dan tekstur. Pengujian organoleptik adalah pengujian yan didasarkan pada proses pengindraan. Pengindraan diartikan sebagai suatu proses fisiopsikologis, yaitu pengenalan alat indra terhadap sifat-sifat benda karena adanya rangsangan yang diterima alat indra yang berasal dari benda tersebut.(Anonim, 2013:1)

Uji organoleptik yang digunakan adalah uji mutu hedonic, yaitu uji yang dilakukan pada panelis. Menurut Bimantara Yoga (2013), uji hedonic adalah pengujian suatu produk dimana panelis dimintai suatu tanggapan pribadi tentang kriteria baik buruk suatu produk yang disajikan. Sedangkan menurut (J. K. Negara, dkk. 2016) pengertian pengujian organoleptik adalah pengujian yang didasarkan pada proses penginderaan. Kemampuan alat indera memberikan kesan atau tanggapan dapat dianalisis atau dibedakan berdasarkan jenis kesan. Kemampuan memberikan kesan dapat dibedakan berdasarkan kemampuan alat indera memberikan reaksi atau rangsangan yang diterima. Kemampuan tersebut meliputi kemampuan mendeteksi (detection), kemampuan mengenali (recognition), kemampuan membedakan (discrimination) dan kemampuan menyatakan suka atau tidak suka (hedonic). Penilaian uji hedonic dilakukan secara spontan, yang kemudian diisikan pada formulir uji hedonic. Tujuan dari uji hedonic adalah untuk mengetahui kualitas kue kering kaastengels dari aspek rasa, warna dan tekstur.

Panelis yang dipilih dalam penelitian ini yaitu panelis terlatih. Jumlah panelis terlatih berjumlah antara 15-25 orang (Soewarno, 1985). Dalam penelitian ini penulis menentukan jumlah panelis yang digunakan yaitu 25 orang, dimana 25 orang merupakan batas maksimal dari panelis terlatih yang diambil dari Dosen Jurusan Pendidikan Kesejahteraan Keluarga/Prodi Tata Boga, Guru-guru di SMK Pariwisata Triatmajaya dan Guruguru di SMKN 2 Singaraja. Dipilihnya 25 panelis tersebut dikarenakan, dalam penelitian ini menggunakan uji organoleptik, dimana dibutuhkan responden sebagai pemeroses respon.25 orang responden tersebut diharapkan dapat memberikan penilaian terhadap kue kaastengels dari aspek rasa, warna dan tekstur.

Instrumen yang digunakan dalam penelitian ini berupa lembar uji kualitas terhadap produk kue kering kaastengels. Pada tabel dibawah menunjukkan lembar uji kualitas kue kering kastengel yang terdiri atas 3 (tiga) tingkatan, dengan kategori yang diberikan adalah baik, cukup dan tidak baik.

Tabel 3.1

Nilai Setiap Panelis

\begin{tabular}{cc}
\hline \multicolumn{2}{c}{ Skala Mutu Hedonik } \\
\hline Kurang & 1 \\
\hline Cukup & 2 \\
\hline Baik & 3 \\
\hline
\end{tabular}

Adapun tolok ukur penilaian untuk uji kualitas kue kaastengels tepung gadung adalah sebagai berikut : 
Jurnal Bosaparis: Pendidikan Kesejahteraan Keluarga

Volume 10, Nomor 2, Juli 2019

Tabel 3.2

Tolak ukur penilaian untuk uji kualitas kue kaastengels tepung gadung

\begin{tabular}{cccc}
\hline Nilai & Rasa & Warna & Tekstur \\
\hline 3 & Gurih, terasa keju & $\begin{array}{c}\text { Warna kuning, } \\
\text { keemasan }\end{array}$ & $\begin{array}{c}\text { Rapuh, tidak } \\
\text { mudah patah }\end{array}$ \\
\hline 2 & $\begin{array}{c}\text { Gurih, tidak terasa } \\
\text { keju }\end{array}$ & $\begin{array}{c}\text { Warna kuning, kurang } \\
\text { keemasan }\end{array}$ & $\begin{array}{c}\text { Kurang rapuh, } \\
\text { mudah patah }\end{array}$ \\
\hline 1 & $\begin{array}{c}\text { Tidak gurih, tidak } \\
\text { terasa keju }\end{array}$ & $\begin{array}{c}\text { Warna tidak kuning dan } \\
\text { tidak keemasan }\end{array}$ & $\begin{array}{c}\text { Rapuh, mudah } \\
\text { hancur }\end{array}$ \\
\hline
\end{tabular}

Tabel 3.3

Lembar penilaian untuk uji kualitas terhadap kue kaastengels

\begin{tabular}{llllllllll}
\hline $\begin{array}{l}\text { Kue kering } \\
\text { kaastengels }\end{array}$ & \multicolumn{3}{c}{ Rasa } & \multicolumn{3}{c}{ Warna } & \multicolumn{3}{c}{ Tekstur } \\
\cline { 2 - 10 } & 1 & 2 & 3 & 1 & 2 & 3 & 1 & 2 & 3 \\
\hline
\end{tabular}

\begin{tabular}{|c|c|}
\hline $\begin{array}{l}\text { Dalam penelitian ini } \\
\text { menggunakan jenis penelitian } \\
\text { eksperimen. Penelitian eksperimen adalah } \\
\text { penelitian yang dibuat dengan sengaja } \\
\text { yang kemudian meneliti akibat yang akan } \\
\text { ditimbulkan. Penelitian ini dilakukan } \\
\text { dengan cara percobaan-percobaan } \\
\text { terhadap subyek yang akan diteliti yaitu } \\
\text { tepung gadung yang diolah menjadi kue }\end{array}$ & 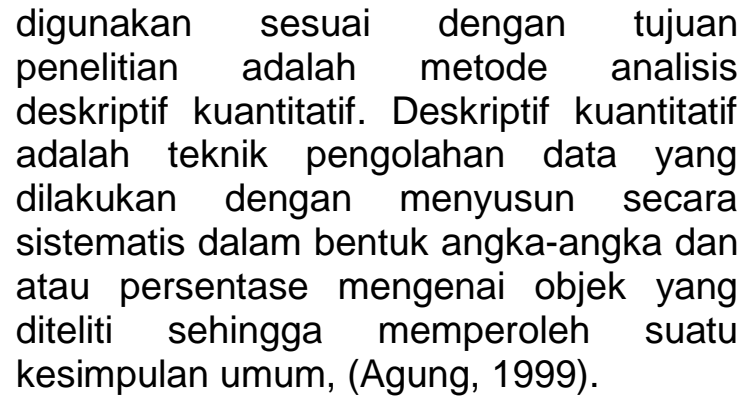 \\
\hline
\end{tabular}
data yang digunakan adalah metode observasi. Metode observasi yaitu suatu cara memperoleh data dengan cara mengadakan pengamatan dan pencatatan secara sistematis tentang suatu objek tertentu. Metode ini digunakan untuk mencari tanggapan panelis terhadap kualitas kue kering kaastengels ditinjau dari aspek rasa, warna dan tekstur. Alat pengumpulan data yang digunakan berupa uji lembar kualitas, (Agung, 1999).

Tujuan yang ingin dicapai dalam penelitian ini yaitu untuk mengetahui kualitas Kue Kering Kaastengels dari tepung gadung ditinjau dari aspek rasa, warna dan tektur. Metode yang relevan

Sesuai dengan metode deskriptif kuantitatif maka kue kering kaastengels tepung gadung dibuat dan diberikan kepada 25 orang panelis untuk diuji dari aspek rasa, warna dan tekstur.Kemudian panelis diharapkan untuk mengisi formulir lembar penilaian uji kualitas, dari masingmasing tingkat kualitas kue kering kastengel menurut variabel penilaian rasa, warna dan tekstur. Masing-masing dari variabel memiliki 3 kriteria tingkat kualitas yang dimana setiap tingkat memilik nilai yang berbeda.

Data yang diperoleh dari panelis kemudian akan di analisi, maka didapatkan sebuah kesimpulan pada 
Jurnal Bosaparis: Pendidikan Kesejahteraan Keluarga

Volume 10, Nomor 2, Juli 2019

kualitas kue kering kaastengels dilihat dari segi rasa, warna dan tekstur dengan kriteria penilaian baik, cukup dan tidak baik. Adapun rumus yang dipergunakan. (Arikunto, 2002)

$$
\mathrm{M}=\frac{\Sigma \mathrm{x}}{N}
$$

Keterangan :

$$
\text { M : Mean (rata-rata) }
$$

$\sum x$ : Jumlah masing-

masing skor (rasa, warna dan tekstur)

$\mathrm{N}$

Jumlah

subjek/sampel

Untuk menentukan kualitas kue kaastengels dianalisis berdasarkan mean (M) dan standar deviasi (SD) dengan mengkonversikan rata-rata presentase ke dalam criteria sebagai berikut. (Koyan. 2012)

$\mathrm{M} \quad=$ Mean atau rata-rata yang dicari

dengan rumus :

$\mathrm{M}=\frac{1}{2} \times$ (Skor maksimum + Skor Minimum)

SD = Standar deviasi yang dicari dengan rumus :
$\mathrm{SD}=\frac{1}{6} \times$ (Skor maksimum - Skor Minimum)

Skor Maksimum : : 3

Skor Minimum $\quad: 1$

Berdasarkan rumus di atas, makan data yang sudah terkumpul akan dicari konversinya. Sehingga mendapatkan hasil sebagai berikut :

Skor Minimum)

$$
\mathrm{M}=\frac{1}{2} \times(\text { Skor Maksimum - }
$$

$$
\begin{aligned}
& M=\frac{1}{2} \times(3+1) \\
& M=2 \\
& S D=\frac{1}{6} \times(\text { Skor Maksimum }
\end{aligned}
$$

- Skor Minimum )

$$
\begin{aligned}
& \mathrm{SD}=\frac{1}{6} \times(3-1) \\
& \mathrm{SD}=0,33
\end{aligned}
$$

Acuan pengambilan keputusan

\begin{tabular}{|c|c|c|}
\hline & Rentangan Skor & Kategori \\
\hline$M+1 S D$ & $\longrightarrow M+3 S D$ & Baik \\
\hline$M-1 S D$ & $\longrightarrow M+1 S D$ & Cukup \\
\hline$M-3 S D$ & $\longrightarrow \mathrm{M}-1 \mathrm{SD}$ & Buruk \\
\hline
\end{tabular}
yang digunakan untuk menentukan kualitas kue kaastengels tepung gadung dari aspek rasa, warna dan tekstur berdasarkan rumus pedoman konversi dengan skala tiga adalah sebagai berikut :

Tabel 3.4

Pedoman konversi skala tiga

(Sumber : Koyan, 2012)

Berdasarkan rumus pedoman

konversi skala tiga maka diperoleh :

$$
\begin{aligned}
2,33-3,00 & =\text { Baik } \\
1,67-2,32 & =\text { Cukup } \\
1,00-1,67 & =\text { Buruk }
\end{aligned}
$$

\section{PEMBAHASAN}

Berdasarkan kualitas kue kering kaastengels tepung gadung yang dibuat oleh peneliti dilaboratorium PKK/Tata Boga Universitas Pendidikan Ganesha memperoleh hasil kue kaastengels dengan menggunakan perbandingan $100 \%$ tepung gadung yang dibuat menggunakan resep kontrol, dapat memenuhi kriteria hasil yang dilihat dari tiga (3) aspek yaitu : rasa, warna dan tekstur. Rasa yang dihasilkan kue kering kaastengels tepung gadung gurih/terasa 
Jurnal Bosaparis: Pendidikan Kesejahteraan Keluarga

Volume 10, Nomor 2, Juli 2019

keju, warna yang dihasilkan kue kering kaastengels tepung gadung kuning keemasan sedangkan pada aspek tekstur yang dihasilkan kue kering kaastengels tepung gadung rapuh dan tidak mudah patah. Hasil kue kaastengels tepung gadung diatas merupakan hasil murni sesuai dengan resep kontrol yang digunakan dalam pembuatan kue kaastengels tepung terigu.

Rasa yang diperoleh dari hasil laboratorium yang diuji kualitas kue kaastengels tepung gadung yang dilihat dari aspek rasa memiliki rasa gurih/terasa keju yang memperoleh skor 2,84 yang sudah terkategori baik. Warna yang dihasilkan dari uji kualitas kue kaastengels tepung gadung memiliki warna kuning keemasan yang dihasilkan dari kuning telur dan memperoleh skor 2,84 yang sudah terkategori baik. Tekstur yang dihasilkan dari uji kualitas kue kaastengels tepung gadung memiliki tekstur rapuh dan tidak mudah patah. Skor yang diperoleh 2.72 yang sudah terkategori baik.
Berikut ini disajikan perhitungan uji kualitas kue kering kaastengels tepung gadung yang dilihat dari aspek rasa, warna dan tekstur.

1. Kualitas rasa dari kue kering kaastengels tepung gadung

$$
\begin{aligned}
& M=\frac{\Sigma \mathrm{x}}{N} \\
& \mathrm{M}=\frac{71}{25} \\
& \mathrm{M}=2,84
\end{aligned}
$$

2. Kualitas warna dari kue kering kaastengels tepung gadung

$$
\begin{aligned}
& \mathrm{M}=\frac{\Sigma \mathrm{x}}{N} \\
& \mathrm{M}=\frac{71}{25} \\
& \mathrm{M}=2,84
\end{aligned}
$$

3. Kualitas tekstur dari kue kering kaastengels tepung gadung

$$
\begin{aligned}
& M=\frac{\Sigma \mathrm{x}}{N} \\
& M=\frac{68}{25} \\
& M=2,72
\end{aligned}
$$

Tabel 4.6

Hasil Uji Kualitas Kue Kering Kaastengels Tepung Gadung

\begin{tabular}{ccccc}
\hline \multirow{2}{*}{$\begin{array}{c}\text { Aspek Yang } \\
\text { Dinilai }\end{array}$} & \multicolumn{4}{c}{ Kue Kering Kaastengels Tepung Gadung } \\
\cline { 2 - 5 } & $\mathbf{\Sigma x}$ & $\begin{array}{c}\text { Jumlah Sampel } \\
\text { (N) }\end{array}$ & Rata-Rata (Mean) & Kategori \\
\hline Rasa & 71 & 25 & 2,84 & Baik \\
\hline Warna & 71 & 25 & 2,84 & Baik \\
\hline Tekstur & 68 & 25 & 2,72 & Baik \\
\hline
\end{tabular}

Berdasarkan tabel diatas diperoleh hasil uji panelis kue kering kaastengels tepung gadung dengan perbandingan $100 \%$ tepung gadung menyatakan kualitas kue kering kaastengels tepung gadung dilihat dari aspek rasa memperoleh skor 2,84 berada pada kategori baik sesuai dengan tolak ukur yaitu gurih/terasa keju. Kualitas warna kue kering kaastengels tepung gadung memperoleh skor 2,84 berada pada kategori baik sesuai dengan tolak ukur yaitu kuning/keemasan. Sedangkan kualitas tekstur kue kering kaastengels tepung gadung memperoleh skor 2,72 berada pada kategori baik sesuai dengan tolak ukur yaitu rapuh dan tidak mudah patah.

Berdasarkan dari hasil uji kualitas kue kering kaastengels tepung gadung dilihat dari aspek rasa, warna dan tekstur dapat dilihat pada diagram batang dibawah ini : 
Jurnal Bosaparis: Pendidikan Kesejahteraan Keluarga

Volume 10, Nomor 2, Juli 2019

Diagram Batang 4.1

Hasil Uji Kualitas Kue Kering Kaastengels Tepung Gadung

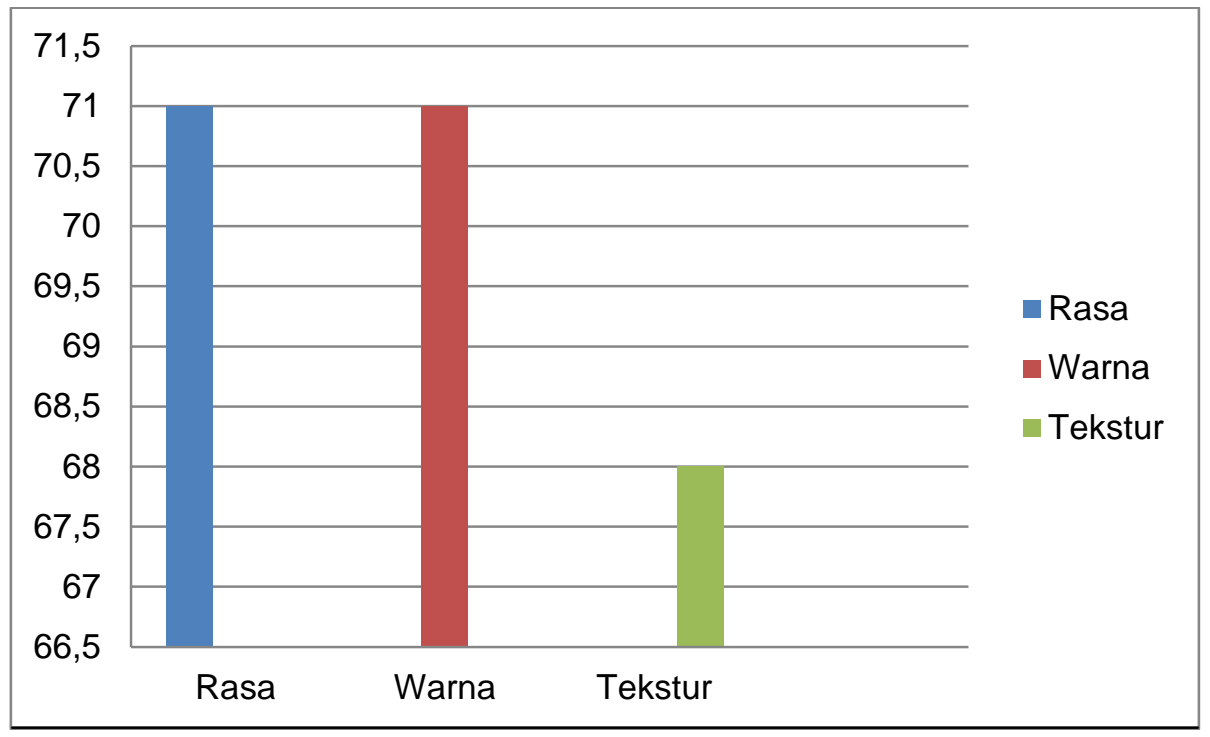

Hasil uji kualitas kue kering kaastengels tepung gadung berdasarkan rasa memperoleh skor 71 pada kategori baik. Hasil uji kualitas kue kering kaastengels tepung gadung berdasarkan warna memperoleh skor 71 pada kategori baik. Sedangkan hasil uji kualitas kue kering kaastengels tepung gadung berdasarkan tekstur memperoleh skor 68 pada kategori baik.

\section{SIMPULAN}

Berdasarkan rumusan masalah dan analisis hasil penelitian, maka kesimpulan yang dapat diambil dalam penelitian ini antara lain hasil uji kualitas kue kering kaastengels tepung gadung dari aspek rasa yang kategori baik yaitu gurih dan terasa keju memperoleh skor rata-rata 2,84, dari aspek warna yang kategori baik yaitu kuning keemasan memperoleh skor rata-rata 2,84, sedangkan dari aspek tekstur yang kategori baik yaitu rapuh dan tidak mudah patah memperoleh skor rata-rata 2,72.
Berdasarkan simpulan penelitian yang telah ditemukan, maka diajukan beberapa saran. Saran-saran yang dimaksud yaitu sebagai berikut :

1. Tepung gadung memiliki kandungan gizi yang cukup baik sehingga berpotensi digunakan sebagai bahan pengganti tepung terigu protein rendah untuk mengurangi ketergantungan pada penggunaan tepung terigu dalam pembuatan produk makanan seperti kue kering.

2. Dalam penelitian selanjutnya tentang pemanfaatan tepung gadung sebaiknya tidak menggunakan substitusi tepung terigu agar mendapat hasil yang lebih optimal.

\section{DAFTAR RUJUKAN}

Agung, AA. Gede. 1999. Metodelogi Penelitian Pendidikan. Singaraja : STKIP Negeri Singaraja.

\section{SARAN}


Jurnal Bosaparis: Pendidikan Kesejahteraan Keluarga

Volume 10, Nomor 2, Juli 2019

Eha, Juleha. 2016 " Pemanfaatan tepung gadung (Discorea Hispida Dennst) pada produksi amilase menggunakan bacillus SP". Tersedia dalam https://ejournal.upi.edu (diakses pada tanggal 9 januari 2019)

Kurnia, Kabelan. 2008. Cara Aman Mengkonsumsi Gadung" Terdapat dalam

Http://kabelan.kurnia.blogspot.co.id ( diakses pada tanggal 4 April 2018 )

Novalinda, Dewi. 2015. " Teknologi pengolahan umbi gadung sebagai sumber bahan pangan lokal" Tersedia dalam Https://jambi.litbang.pertanian.go.id (diakses pada tanggal 9 April 2018)

Rosmeri, dkk. 2013. "Pemanfaatan Tepung Umbi Gadung (Dioscorea Hispida Dennst) dan Tepung MOCAF (Modified Cassava Flour) Sebagai Substitusi dalam Pembuatan Mie Basah, Mie Kering, dan Mie Instan" tersedia dalam http://ejournal-s1.undip.ac.id (diakses pada tanggal 19 Mei 2018)

Rukmana, Rahmat. 2001. "Aneka Kripik Umbi" Yogyakarta : PT Kanisius

Yoga, Bimantara. 3013. Uji Organoleptik. Tersedia dalam https://bimantarayoga.blogspot.co m (diakses pada tanggal 3 Mei 2018) 